\title{
Polymeric Hydrogels for Controlled Release of Black Tea and Coffee Extracts for Topical Applications
}

\author{
Pooja Makhija ${ }^{1, *(\mathbb{D}}$, Himanshu Kathuria ${ }^{2,3}{ }^{(D)}$, Gautam Sethi ${ }^{4}$ and Bert Grobben ${ }^{5, *(\mathbb{C}}$ \\ 1 Department of Chemistry, National University of Singapore, 3 Science Drive 3, Singapore 117543, Singapore \\ 2 Department of Pharmacy, National University of Singapore, Singapore 117543, Singapore; \\ himanshukathuria01@u.nus.edu \\ 3 Nusmetic Pvt Ltd., Makerspace, i4 Building, 3 Research Link, Singapore 117602, Singapore \\ 4 Department of Pharmacology, Yong Loo Lin School of Medicine, National University of Singapore, Blk MD3, \\ 16 Medical Drive, Singapore 117600, Singapore; phcgs@nus.edu.sg \\ 5 Budding Innovations Pvt Ltd., 06-02 Jellicoe Rd, Singapore 208766, Singapore \\ * Correspondence: pooja@u.nus.edu (P.M.); bert.grobben@budinno.com (B.G.)
}

Citation: Makhija, P.; Kathuria, H.; Sethi, G.; Grobben, B. Polymeric Hydrogels for Controlled Release of Black Tea and Coffee Extracts for Topical Applications. Gels 2021, 7, 174 https://doi.org/10.3390/gels7040174

Academic Editor: Maria Valentina Dinu

Received: 22 September 2021

Accepted: 19 October 2021

Published: 21 October 202

Publisher's Note: MDPI stays neutral with regard to jurisdictional claims in published maps and institutional affiliations.

Copyright: (C) 2021 by the authors Licensee MDPI, Basel, Switzerland. This article is an open access article distributed under the terms and conditions of the Creative Commons Attribution (CC BY) license (https:// creativecommons.org/licenses/by/ $4.0 /)$.

\begin{abstract}
Tea and coffee are popular beverages. Both are also used in topical applications, such as ultraviolet (UV) protection, anti-aging, and wound healing. However, the impact of tea and coffee extract on skin cells is minimally explored. This study investigated the direct exposure of tea and coffee extract on skin cells using a 3-(4,5-dimethylthiazol-2-yl)-2,5-diphenyl-2H-tetrazolium bromide (MTT) assay. It was found that direct exposure of tea and coffee to skin cells can be toxic at a high dose on prolonged exposure $(72 \mathrm{~h})$. Therefore, it was hypothesized that a formulation providing a controlled release of tea and coffee could improve their skin compatibility. Thermally cross-linked poly(acrylic acid) hydrogels loaded with tea and coffee extracts (with and without milk) were formulated and optimized. The release profiles of these hydrogels were studied at varying loading efficiency. Milk addition with tea extract retarded the tea extract release from hydrogel while minimally affecting the coffee release. This effect was due to the molecular interaction of tea with milk components, showing changes in size, zeta potential, and polydispersity index. The release study best fitted the Korsmeyer-Peppas release model. Skin cells exposed to tea or coffee-loaded hydrogel showed normal skin cell morphology under fluorescence microscopic analysis. In conclusion, the hydrogels controlled the tea and coffee release and showed biocompatibility with skin cells. It can potentially be used for skin applications.
\end{abstract}

Keywords: black tea; coffee; hydrogel; poly(acrylic acid); topical; tea milk interaction; coffee milk interaction

\section{Introduction}

Black tea (Camellia sinensis var. assamica) and coffee (Coffea arabica) are popular beverages, which provide several medicinal benefits. Black tea is industrially produced by the oxidation of green tea [1-3]. During the oxidation process, green tea catechins are partially converted into black tea polyphenols, such as theaflavins and thearubigins [1]. The dark orange color of black tea decoction is majorly due to theaflavins (theaflavin, theaflavin-3-O-gallate, theaflavin-3'-O-gallate, theaflavin-3,3'-O,O-digallate) [1]. It contains xanthines (caffeine, theobromine, and theophylline), catechins (epicatechin, epigallocatechin, epicatechin gallate, epigallocatechin gallate), and small amounts of isotheaflavin, neotheaflavin, theaflavate A, theaflavate B, isotheaflavin-30-O-gallate, neotheaflavate-3O-gallate, theaflavic acids, theaflagallins, and methylated theaflavins [1,4-7]. Coffee is mainly obtained from Coffea arabica. Its main constituents are caffeic acid, chlorogenic acids, caffeine, cafestol, ferulic acid, pyrogallic acid, trigonelline, kahweol, hydroxycinnamic acid, 5-caffeoylquinic acid, nicotinic acid, pyrocatechol [8-14].

Several reports show that tea extract, coffee extracts, and their components have multiple bioactivities [10,15-28]. These can be used to treat various skin conditions like 
wounds, cellulitis, ultraviolet (UV) damage, acne, and aging [15-21]. The potential topical applications of these extracts are protection from oxidative stress and UV damage [22-27], anti-inflammatory [11,28,29], wound-healing [30-33], and sunscreen properties [34]. Green tea polyphenols were developed into microspheres by oxidative coupling, and loaded into polyvinyl alcohol/alginate hydrogel, later studied for diabetic wound healing [35,36]. A hair care formulation containing tea extract showed efficacy in UV damage prevention [37]. In a randomized, single-blind trial, a green tea extract with other extracts in hydrogel formulation showed antiacne and antiblotch efficacy, where hydrogel use over a period showed superior effects than $1 \%$ clindamycin gel [38]. 'Silver needle white tea' extract-treated wounds showed less inflammation and more angiogenesis than vehicletreated wounds [31]. Green tea extracts showed wound healing potential in NIH3T3 fibroblast cells [39]. Coffee extracts are used in cosmetic products, which are commercially available $[40,41]$. Other studies show that an ointment containing coffee extract had woundhealing properties [42], and a gel containing green coffee and resveratrol protects dental caries [43]. Coffee extract incorporated in cellulose dressings showed enhanced antimicrobial activity [44]. Another group developed nanostructured lipid carriers encapsulating caffeine for the treatment of cellulitis [45,46].

The addition of milk to tea and coffee beverages has been an age-old practice that improves sensory acceptance. Several reports explored milk and its components, such as proteins, as a carrier for the delivery of tea extracts, coffee extracts, and its components. Tea polyphenols are known to interact with milk, and the potential role of milk as a carrier of tea components has been discussed in multiple studies [47-54]. Tea polyphenols have low chemical stability, and their interactions with milk proteins improve their stability $[50,55,56]$. In another study, liposomes prepared from milk phospholipids could protect ascorbic acid for seven weeks, a rapidly oxidizable molecule [57]. Milk-based liposomes have also been used to deliver epigallocatechin gallate (EGCG) [51]. Casein can bind EGCG without changing its activity $[48,49]$ and selectivity [48], showing the appropriateness of casein micelles for polyphenol delivery $[48,49]$. In the case of coffee extracts, chlorogenic acid is the most studied interaction. It was found that chlorogenic acid binds with milk components, reducing antioxidant activity and bioavailability [58]. Chlorogenic acids interact with major milk proteins, i.e., $\alpha$-casein, $\beta$-casein, $\mathrm{k}$-casein, $\alpha$-lactalbumin, and $\beta$-lactoglobulin via different bonding mechanisms resulting in reduced antioxidant activity [59]. The other green coffee components, such as caffeic, ferulic, and chlorogenic acids, also interact with milk proteins [60].

Poly(acrylic acid) (PAA) polymer, known as carbomer, is a widely known safe ingredient used in pharmaceutical and cosmetic applications. Turkoglu et al. showed protection against UV damage using aqueous black tea extract loaded into a carbomer gel showed UV damage (erythema) protection in human subjects [61,62]. Recently, Ngamdokmai et al. showed carbopol 940 (a carbomer) gel with emulsion loaded with tea and coffee extracts for cellulite application [15]. Though commercially available carbomers can be formed into gels, they do not provide three-dimensional structure and rigidity for specialized applications such as facial film masks for topical use. Therefore, researchers explored a synthetic approach to prepare PAA hydrogels [63]. Zhu et al. prepared hybrid hydrogel with PAA and peptide for wound dressings with stimuli sensitivity and biodegradability [64].

Though the tea and coffee interaction with milk is known, the impact of milk on tea or coffee release from hydrogels or other delivery systems is not known. Therefore, in this study, the PAA hydrogel loaded with tea and coffee extracts was prepared, and later, the impact of milk on tea and coffee release was checked. First, the cell viability of tea and coffee extract on direct exposure to skin cells was measured. Then, PAA hydrogels loaded with tea and coffee extracts were prepared and optimized. Later, the loading efficiency and release kinetics of hydrogels were studied, along with the effect of milk addition. Finally, the skin cell morphology with exposure to tea and coffee-loaded hydrogels was evaluated. 


\section{Results and Discussion}

\subsection{Calibration Curves of Black Tea Extract and Coffee Extract}

The yield of black tea dry extract was found in a range of $0.1 \% w / w$. It is seen from the literature that the $\lambda_{\text {max }}$ of known black tea extract and coffee components is in the range of 200-500 $\mathrm{nm}$. Therefore, all the dilutions of the calibration curve of black tea extract (Figure 1a) and coffee extract (Figure 1b) are represented in the 200-500 nm range. These calibration curves were used to generate linear equations (Figure S1) to determine the values of unknown tea and coffee solution concentrations in release and entrapment studies.

(a) Black tea

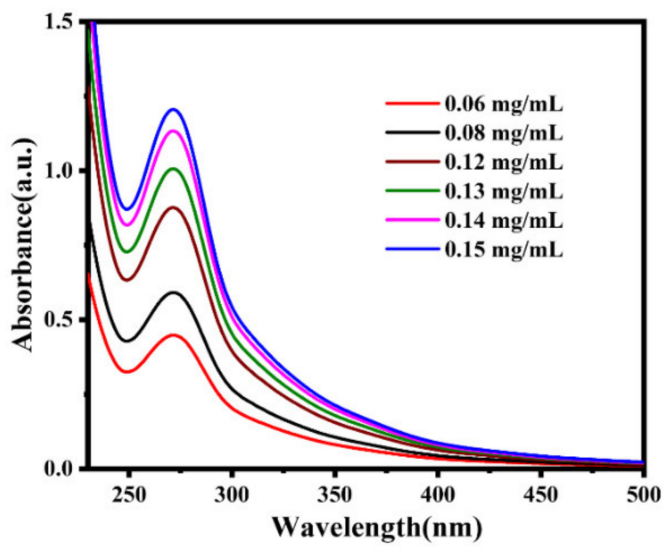

(b) Coffee

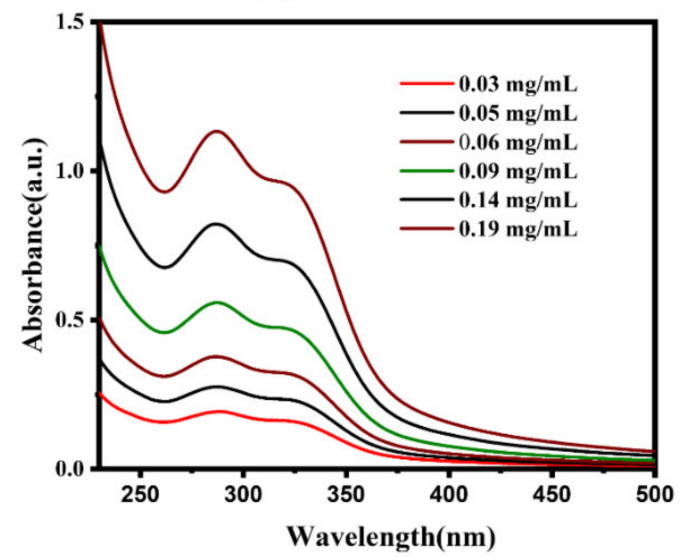

Figure 1. (a) UV-Vis spectra for calibration curve construction of (a) black tea extract in a range of $0.06-0.15 \mathrm{mg} / \mathrm{mL}$. (b) coffee extract in a range of $0.03-0.19 \mathrm{mg} / \mathrm{mL}$.

\subsection{Cell Viability Assessment of Extracts}

There is a lack of understanding of the impact of black tea extract and coffee extracts on skin cells. Therefore, the cell viability of tea and coffee extracts was studied on the human skin keratinocytes (HaCaT cells) cells using 3-(4,5-dimethylthiazol-2-yl)-2,5-diphenyl-2Htetrazolium bromide (MTT) assay as described previously [65]. The cell viability (\%) was calculated using Equation (1). Figure 2a,b show the cell viability of HaCaT cells on being treated with $0.05-2 \mathrm{mg} / \mathrm{mL}$ of black tea and coffee extracts for $72 \mathrm{~h}$, respectively. The cell viability of black tea extract was $118 \pm 6 \%-6 \pm 1.9 \%$, whereas the cell viability for the coffee extract was $99.5 \pm 6 \%-6 \pm 1.8 \%$. The cell viability values decreased drastically after the $0.1 \mathrm{mg} / \mathrm{mL}$ dose (tea extract) and $0.5 \mathrm{mg} / \mathrm{mL}$ dose (coffee extract). The tea and coffee extracts' half-maximum inhibitory concentration (IC50) were $0.35 \mathrm{mg} / \mathrm{mL}$ and $0.56 \mathrm{mg} / \mathrm{mL}$, respectively.
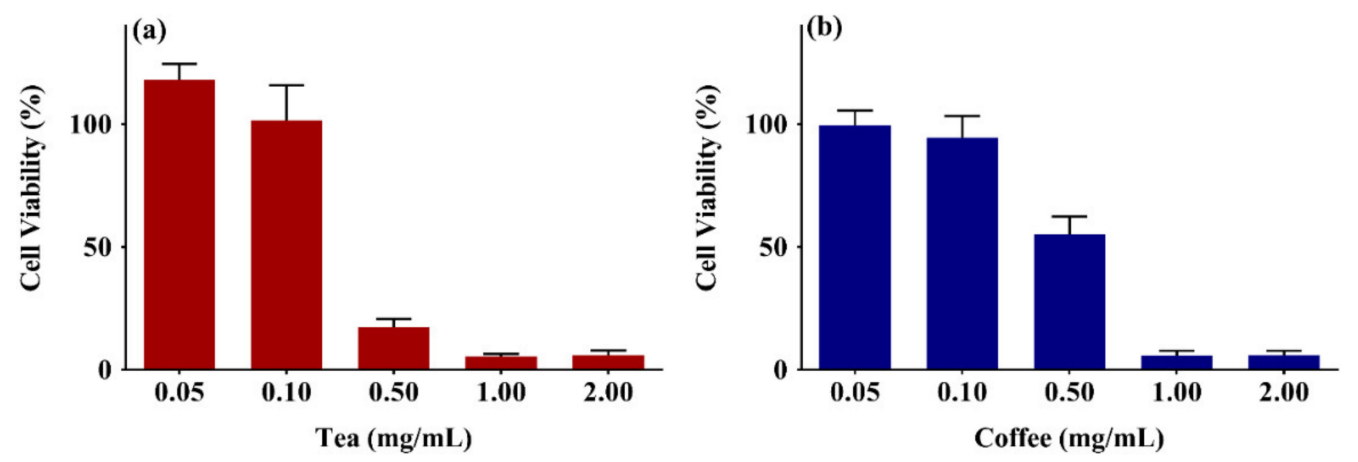

Figure 2. Cell viability study of (a) black tea extract, (b) coffee extracts on HaCaT cells using MTT assay. The results from three independent experiments ( 3 replicates in each experiment) are presented as mean \pm standard deviation (SD). 
Previously the $\mathrm{IC}_{50}$ value of black tea extract has been reported as $0.56 \mathrm{mg} / \mathrm{mL}$ against the Caco-2 cells after $48 \mathrm{~h}$, while the same extract was not cytotoxic to fibroblasts at this concentration [66]. Another study reported the $\mathrm{IC}_{50}$ values of black tea extracts as $1.4 \times 10^{-6} \mathrm{mg} / \mathrm{mL}$ (HT-29 cells), $1.6 \times 10^{-6} \mathrm{mg} / \mathrm{mL}$ (MCF-7 cells), $>5 \times 10^{-3} \mathrm{mg} / \mathrm{mL}$ (A549 cells), and $>5 \times 10^{-3} \mathrm{mg} / \mathrm{mL}$ (NIH-3T3 cells) [67]. A recent study reported the $\mathrm{IC}_{50}$ (48 h) of black tea extracts as $0.57 \mathrm{mg} / \mathrm{mL}$ and green tea extracts as $0.52 \mathrm{mg} / \mathrm{mL}$ against HepG2 cells [68], which are closer to $\mathrm{IC}_{50}$ obtained on $\mathrm{HaCaT}$ cells in our study.

Similarly, coffee extracts have also been evaluated for cytotoxicity against several in-vitro models. Coffea canephora var. robusta extracts also showed cytotoxicity against prostate cancer cells DU-145 [69]. Extracts from film removed from raw coffee beans were non-cytotoxic concentrations at and above $0.2 \mathrm{mg} / \mathrm{mL}$ against skin keratinocytes [70]. Methanolic extracts of low-grade green coffee beans and spent coffee beans were cytotoxic against leukemia cells (P388) [71]. Another study reported $\mathrm{IC}_{50}$ values $(24 \mathrm{~h})$ of roasted coffee extracts as $4.88 \mathrm{mg} / \mathrm{mL}$ against fibroblasts (L929) [72]. It is clear from the literature that the tea and coffee extracts are cytotoxic after a specific dose range, and the cytotoxicity also depends upon the source of the extract [73].

\subsection{Preparation of Hydrogels}

The hydrogels were prepared from modified formulae from Joshi et al. [74]. The PAA amount was optimized to get the desired hydrogel properties (Figure S2, Table S1). Figure 3a shows the schematic of the hydrogel preparation process for the blank hydrogel, extract loaded, and extract with milk loaded hydrogels. The blank hydrogel was transparent, while tea and coffee hydrogels were brown in appearance. The milk addition reduced the intensity of the brown color and provided a milky appearance. The texture of hydrogels was rigid, adhesive, and firm.

(a)
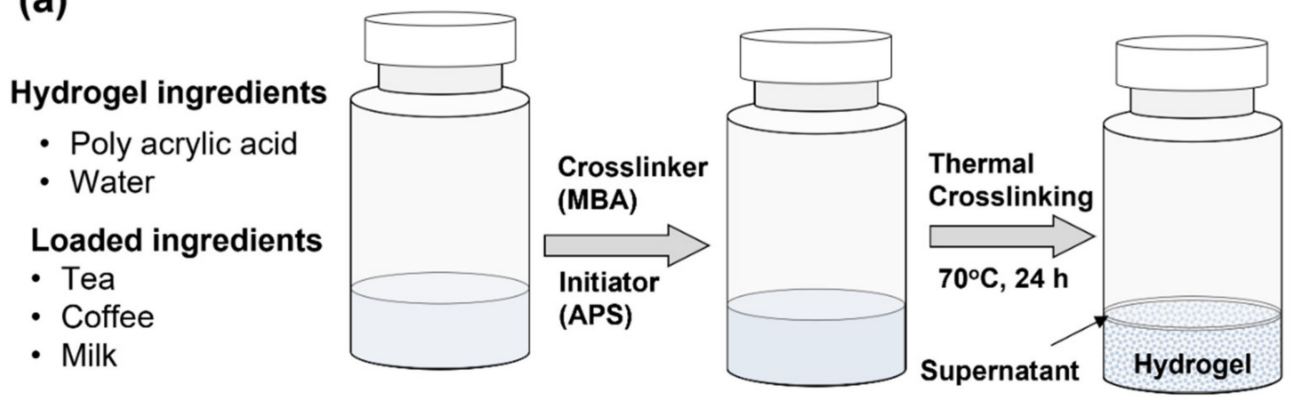

Blank Hydrogel
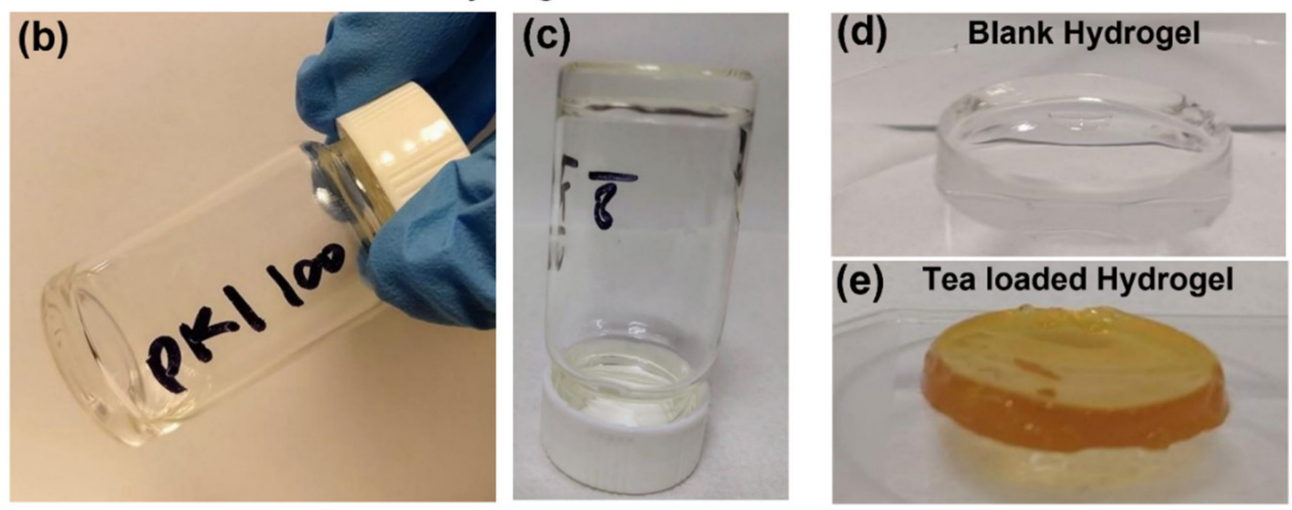

Figure 3. (a) Schematic of the hydrogel preparation process. (b-d) shows blank hydrogel formulae D (Table S1). (e) show the image of tea-loaded hydrogel. 


\subsection{Determination of Extract Loading in Hydrogels}

Formulation D from Table S1 was selected for further incorporation of extracts during the gelling process. Incorporating a high amount $(20 \mathrm{mg}$ or more) of tea or coffee extracts interfered with the gelling process (Figure S3, Video S1). Therefore, different amounts of ammonium persulfate (APS) and N,N'-Methylenebisacrylamide (MBA) were optimized for complete gelling and achieving sufficient extract loading (Figure S3, Table S2). Finally, PAA, APS, and MBA quantities like formulation GT (Table S2) were selected to load different amounts of tea, tea-milk, coffee, and coffee-milk in hydrogels (Figure 4.) After $24 \mathrm{~h}$ of gelation, the supernatant liquid from individual gels (Figure 4, top layer of each hydrogel marked by black arrow) was collected. The supernatant was suitably diluted and analyzed using a Shimadzu UV-Vis spectrophotometer (UV-3600) in a wavelength range of $200-800 \mathrm{~nm}$. The concentrations of the samples were determined using the calibration curve equation prepared using known quantities of the tea and coffee extract powder (Figure S1). The total amount of tea or coffee was expected to be the sum of the amount of tea or coffee remaining in the supernatant plus the amount entrapped in the hydrogel, considering no other factors contributed to the loss of tea or coffee. The extract loading in hydrogels of each hydrogel was estimated as loading efficiency, calculated using Equation (2). Table 1 shows the loading efficiencies of all 16 hydrogels prepared using varying amounts of dry extracts with and without milk. All values of the loading efficiencies were found to be in the range of $69-96 \%$. Black tea extract-loaded hydrogels (30T, 40T, 50T, and 60T) showed efficiency from $90 \pm 1 \%-92 \pm 4 \%$. On addition of milk, the values ranged from $75 \pm 6 \%-84 \pm 4 \%$ in formulation batches $30 \mathrm{TM}, 40 \mathrm{TM}, 50 \mathrm{TM}$, and 60TM. The loading efficiencies of coffee extract hydrogels without milk were in the range of $88 \pm 1 \%-89 \pm 4 \%$, whereas efficiencies of coffee extract hydrogels with milk were in the range of $84 \pm 4 \%-82 \pm 3 \%$. However, milk addition did not impact the efficiency of the gelling system in a statistically significant manner. It is also clear that the loading efficiencies were not impacted by the original amount of tea or coffee extract added $(3-60 \mathrm{mg})$ to the gelling system across similar formulations.

Table 1. Loading efficiencies of different hydrogel formulations.

\begin{tabular}{cccc}
\hline Code & Loading Efficiency (\%) & Code & Loading Efficiency (\%) \\
\hline $30 \mathrm{~T}$ & $90 \pm 1$ & $30 \mathrm{TM}$ & $75 \pm 6$ \\
$40 \mathrm{~T}$ & $90 \pm 2$ & $40 \mathrm{TM}$ & $78 \pm 8$ \\
$50 \mathrm{~T}$ & $91 \pm 2$ & $50 \mathrm{TM}$ & $80 \pm 7$ \\
$60 \mathrm{~T}$ & $92 \pm 4$ & $60 \mathrm{TM}$ & $84 \pm 4$ \\
$30 \mathrm{C}$ & $88 \pm 1$ & $30 \mathrm{CM}$ & $84 \pm 4$ \\
$40 \mathrm{C}$ & $87 \pm 2$ & $40 \mathrm{CM}$ & $78 \pm 6$ \\
$50 \mathrm{C}$ & $86 \pm 2$ & $50 \mathrm{CM}$ & $83 \pm 3$ \\
$60 \mathrm{C}$ & $89 \pm 4$ & $60 \mathrm{CM}$ & $82 \pm 3$ \\
\hline
\end{tabular}

$\mathrm{T}=$ Black tea extract; $\mathrm{TM}=$ Black tea extract and milk, $\mathrm{C}=$ coffee extract, $\mathrm{CM}=$ coffee extract and milk, $\mathrm{B}=$ blank formulation without milk, $\mathrm{BM}=$ blank formulation with milk; $30=30 \mathrm{mg}$ of extract; $40=40 \mathrm{mg}$ of extract; $50=50 \mathrm{mg}$ of extract; $60=60 \mathrm{mg}$ of extract. The results from three independent experiments ( 3 replicates in each experiment) are presented as mean \pm standard deviation (S.D.). Unpaired t-test with Welch's correction was applied.

\subsection{Release Profile and Area under the Curve (AUC) of Tea and Coffee Hydrogels with or without Milk}

The diameter of each gel was $1.3 \mathrm{~cm}$. Cumulative tea released after $4 \mathrm{~h}$ was $1.4 \pm 0.1 \mathrm{mg}$ for $30 \mathrm{~T}, 2 \pm 0.1 \mathrm{mg}$ for $40 \mathrm{~T}, 3.5 \pm 0.3 \mathrm{mg}$ for $50 \mathrm{~T}$, and $3.3 \pm 1.7 \mathrm{mg}$ for $60 \mathrm{~T}$. On the addition of milk, the cumulative tea release was $0.8 \pm 0.7 \mathrm{mg}$ (30TM), $1.5 \pm 0.1 \mathrm{mg}(40 \mathrm{TM})$, $1.8 \pm 0.2 \mathrm{mg}(50 \mathrm{TM})$, and $1.8 \pm 0.2 \mathrm{mg}(60 \mathrm{TM})$. No definite trend can be deduced in the very initial hours of release. The cumulative tea release after $120 \mathrm{~h}$ ( 5 days) values were $4.9 \pm 0.1 \mathrm{mg}(30 \mathrm{~T}), 7.2 \pm 1.0 \mathrm{mg}(40 \mathrm{~T}), 9.7 \pm 0.5 \mathrm{mg}(50 \mathrm{~T}), 13.2 \pm 1.7 \mathrm{mg}(60 \mathrm{~T}), 3.4 \pm 0.5 \mathrm{mg}$ (30TM), $4.2 \pm 0.9 \mathrm{mg}(40 \mathrm{TM}), 5 \pm 0.6 \mathrm{mg}(50 \mathrm{TM})$, and $5.2 \pm 0.5 \mathrm{mg}(60 \mathrm{TM})$. The release profile of all eight formulations showed a similar trend, although the extent of release was different between the tea hydrogel versus tea-milk hydrogel. It appeared that milk 
hindered the release of tea from the hydrogels (Figure 5). The cumulative coffee release between the first $(4 \mathrm{~h})$ and last $(120 \mathrm{~h})$ studied release were $1.8 \pm 0.7-4.2 \pm 0.2 \mathrm{mg}(30 \mathrm{C})$, $1.8 \pm 0.4-5.8 \pm 1.2 \mathrm{mg}(40 \mathrm{C}), 2.4 \pm 0.7-6.4 \pm 0.2 \mathrm{mg}(50 \mathrm{C}), 2.9 \pm 0.2-8.1 \pm 0.2 \mathrm{mg}(60 \mathrm{C})$, $1.5 \pm 0.7-7.8 \pm 0.2 \mathrm{mg}(30 \mathrm{CM}), 0.8 \pm 0.4-4.8 \pm 0.7 \mathrm{mg}(40 \mathrm{CM}), 1.9 \pm 0.3-5.6 \pm 0.3 \mathrm{mg}$ (50CM), and $2.9 \pm 1.9-6.9 \pm 0.7 \mathrm{mg}(60 \mathrm{CM})$. It appears that the release of coffee extract from the gel was not dependent on the presence or absence of milk (Figure 5). The release profile showed the best fitting into the Korsmeyer-Peppas model (Tables S3 and S4) in all except one formulation. This model works well with the formulations releasing the active through diffusion and erosion. The polymer surface looks eroded, and a decrease in color intensity of the brown surface (not shown). It is also noteworthy that the gels did not release the coffee or black tea extract entirely even after five days (physical observation by color).
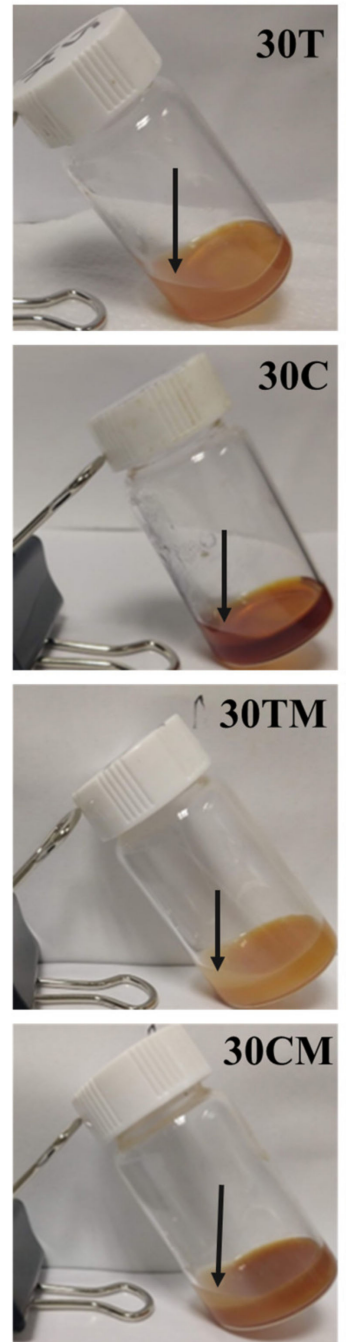
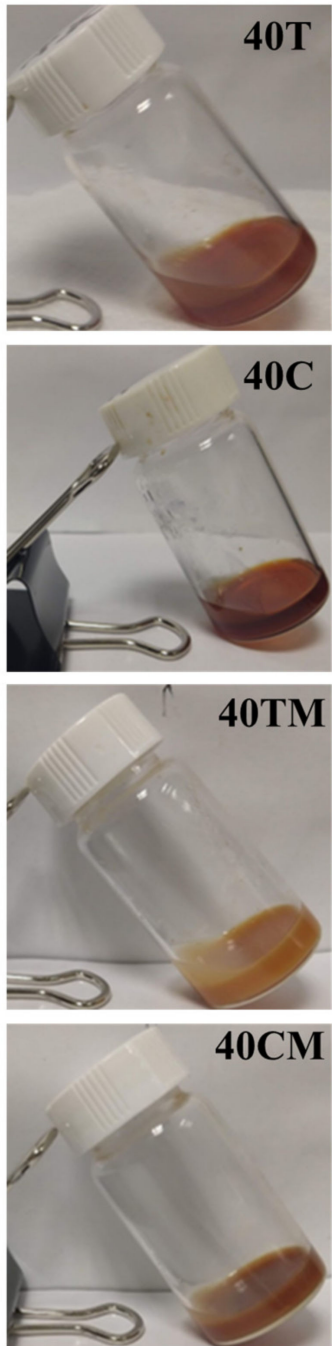
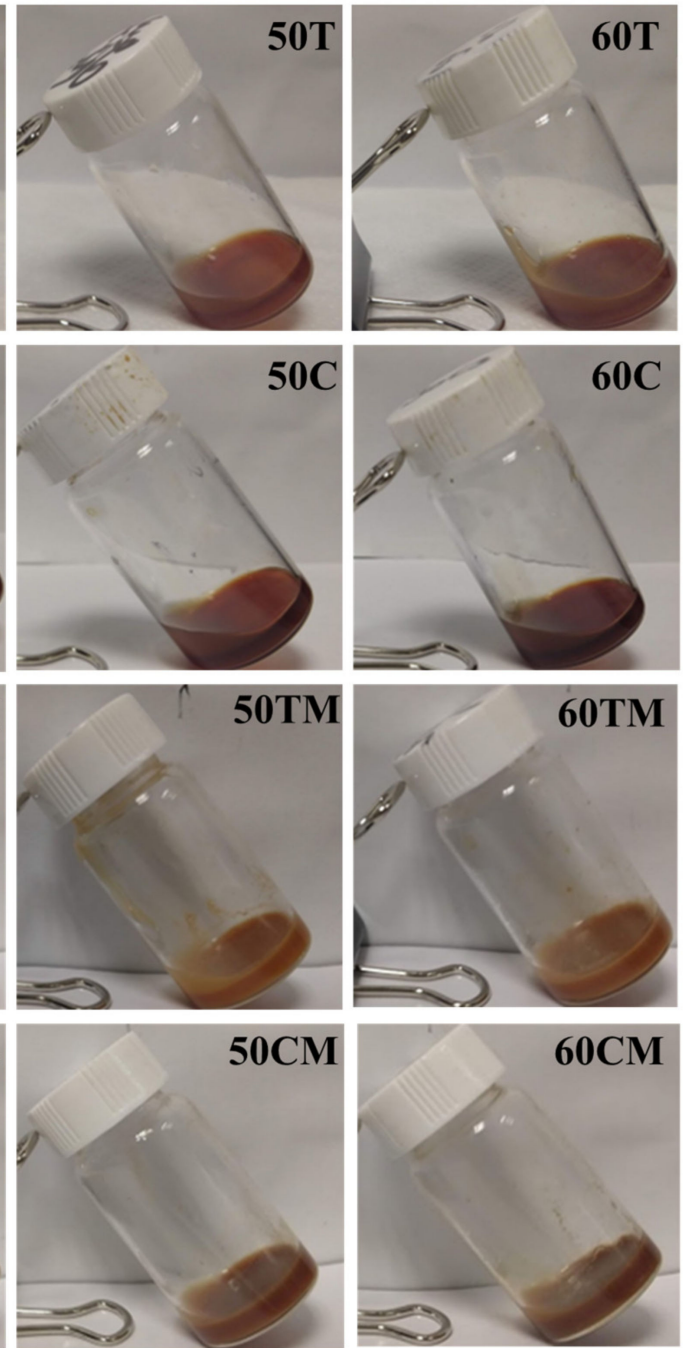

Figure 4. Physical observation of hydrogels after completion of the gelling period. Different hydrogels are shown here, incorporating tea or coffee with or without milk. The black arrow marks supernatant in the top layer of hydrogel. 

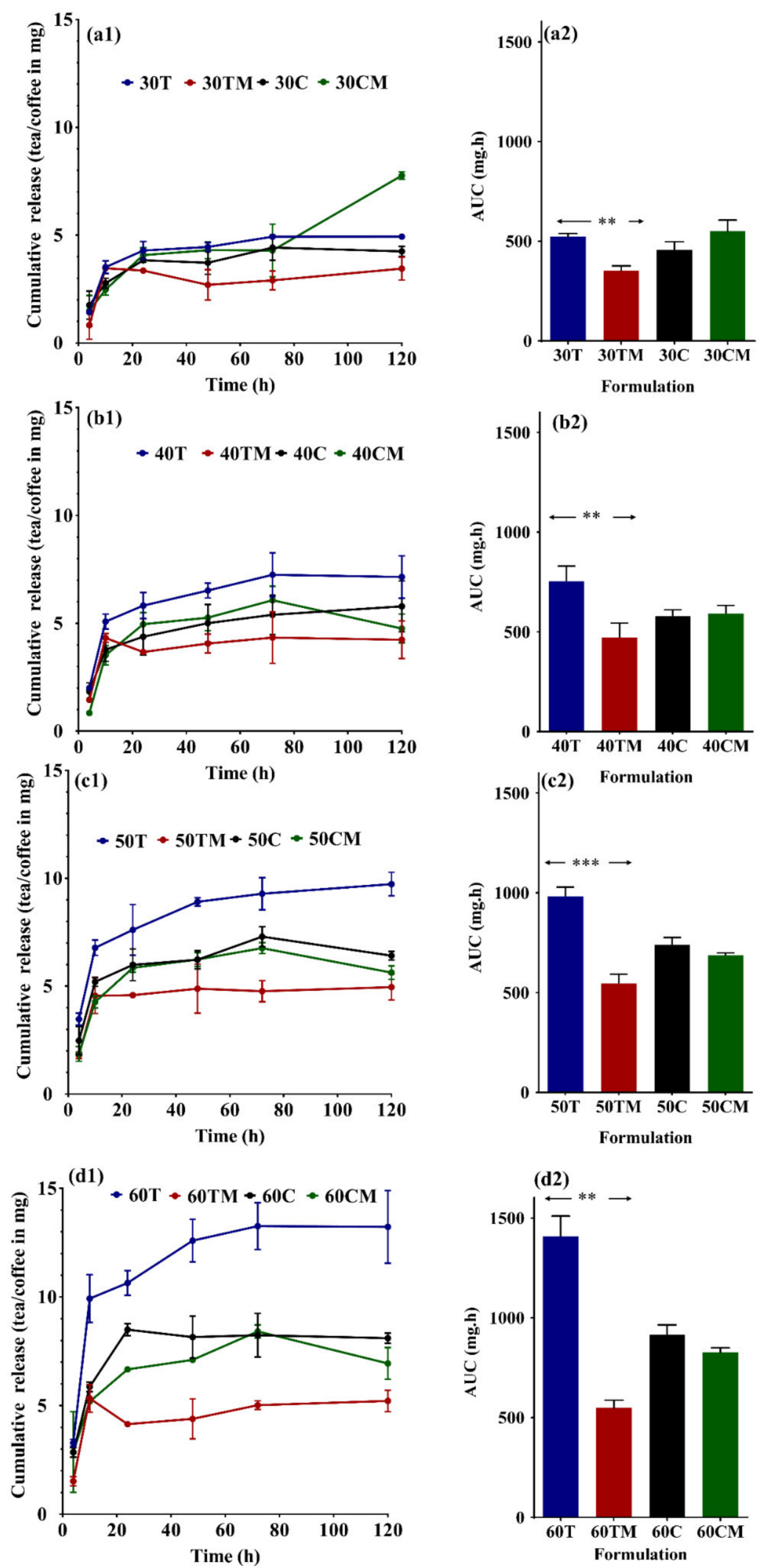

Figure 5. (a1-d1): Cumulative tea release over time from the different hydrogels for $120 \mathrm{~h}$ for different tea and coffee hydrogel formulations. (a2-d2): Area under the curve from the individual curve of cumulative tea release for $120 \mathrm{~h}$ the different hydrogels. The results from three independent experiments ( 3 replicates in each experiment) are presented as mean \pm standard deviation (SD). Unpaired $t$-test with Welch's correction was applied, ${ }^{* *}$ indicate $p<0.01, * * *$ indicate $p<0.001$. 
The AUC of different formulations of tea, tea-milk, coffee, coffee-milk, and different formulation codes 30,40,50, and 60 were compared to highlight the impact of addition of milk. It appears that the release of coffee extract from the gel was not dependent on the presence or absence of milk. Figure 5 shows a significant difference between tea and tea-milk hydrogel AUC's for all the different formula codes 30,40, 50, and 60, whereas, in coffee versus coffee-milk hydrogels, none of the AUC's were significant from each other. Few studies have reported that the tea catechins and milk proteins bind together, impacting the bioavailability [47-54,75]. Likewise, in this study, milk interaction with black tea has acted as a natural control release agent. However, for coffee, only interactions of chlorogenic acids with milk are known [58-60], which amounts to $4-11 \% w / w$ in instant coffee [76]. Our study also utilized freeze-dried (instant) coffee, so the levels of chlorogenic acid should be similar. Though the interactions of chlorogenic acid and milk are known, the milk addition did not further control the release of coffee. This can be attributed to stronger interaction of milk with tea components compared to milk interactions with coffee components.

Understanding the hydrogel's release behavior is essential to estimate the amount of extract released in the system. There are different kinetic models based on mathematical calculations to calculate drug release from different formulations. In this study, release data from all 16 formulations were fitted into five types of release models: zero-order, first-order, Higuchi model, Hixson-Crowell, and Korsmeyer-Peppas model [77]. The $\mathrm{R}^{2}$ value closest to 1 was considered the measure of best fitting in the model. The mathematical analysis of the release data in Tables S3 and S4 showed the Korsmeyer-Peppas equation for all formulations except 30CM. Therefore, the Korsmeyer-Peppas model is more suitable for understanding the release of these hydrogel formulations than any other model. Furthermore, evidence in the literature points out the suitability of this model for formulations with polymer matrices such as hydrogel [77].

\subsection{Interaction of Coffee and Tea with Milk}

As observed in Section 2.5, the tea release from hydrogels was affected by the milk addition. Therefore, particle size and $\zeta$-potentials were measured for black tea extract or coffee extract in water or milk-water (1:15) mixture. Table 2 shows the impact of milk on particle size and $\zeta$-potentials. The addition of milk $(-26.0 \pm 0.404 \mathrm{mV})$ to tea $(-10.5 \pm 0.115 \mathrm{mV})$ brings the zeta potential of milk and tea solution to $-20.0 \pm 0.346 \mathrm{mV}$. However, the zeta potential of coffee $(-10.8 \pm 0.586 \mathrm{mV})$ and coffee with milk $(-15.2 \pm 0.351 \mathrm{mV})$ does not change much. The polydispersity index (PDI) of tea $(0.318 \pm 0.005)$ and coffee $(0.384 \pm 0.048)$ were higher than milk $(0.248 \pm 0.008)$, milk-tea $(0.256 \pm 0.008)$, and milkcoffee $(0.280 \pm 0.006)$ solutions. Thus, the PDI of tea or coffee with milk shows that milk reduces polydispersity, resulting from interaction with milk. The average hydrodynamic diameter (Zavg) of tea with milk was $295 \pm 3 \mathrm{~nm}$ compared with $459 \pm 13 \mathrm{~nm}$ for tea, indicating interactions leading to a smaller size. Similarly, Zavg of coffee with milk was $371 \pm 6 \mathrm{~nm}$ compared with $467 \pm 21 \mathrm{~nm}$ for coffee.

Table 2. Effect of milk addition on the zeta potential and Zavg (d.nm) of tea and coffee extracts.

\begin{tabular}{cccc}
\hline Sample & Zeta Potential $(\mathbf{m V})$ & Zavg $($ d.nm) & PDI \\
\hline Milk & $-26.0 \pm 0.404$ & $350 \pm 3$ & $0.248 \pm 0.008$ \\
Tea & $-10.5 \pm 0.115$ & $459 \pm 13$ & $0.318 \pm 0.005$ \\
Coffee & $-10.8 \pm 0.586$ & $467 \pm 21$ & $0.384 \pm 0.048$ \\
Tea + Milk & $-20.0 \pm 0.346$ & $295 \pm 3$ & $0.256 \pm 0.008$ \\
Coffee + Milk & $-15.2 \pm 0.351$ & $371 \pm 6$ & $0.280 \pm 0.006$ \\
\hline
\end{tabular}

Zavg = average hydrodynamic diameter; PDI = Polydispersity Index. 


\subsection{Morphological Analysis of Cells in the Presence of Extracts}

In this section, the impact of tea and coffee on $\mathrm{HaCaT}$ cell viability was observed. This experiment was done to observe the impact of tea or coffee extracts on the HaCaT cell morphology. The extracts (tea or coffee) were added to HaCaT cells for $12 \mathrm{~h}$. It was found that treating $\mathrm{HaCaT}$ cells with $1.5 \mathrm{mg} / \mathrm{mL}$ of tea or coffee extracts, even for a short treatment of $12 \mathrm{~h}$, drastically impacted the morphology. Figure 6 shows that the coffee and black tea extract-treated cells are distorted in shape compared to control cells. In black tea extract-treated cells, even the cell membrane (red color) is not visible surrounding the nucleus. Instead, there are fragments of the membrane (indicated by arrows) shown in Figure 6. Previously, black tea theaflavins distorted gastric carcinoma cells (KATO-III) morphology [78]. Recently, black tea has been reported to distort the cell morphology of HepG2 cells (cell shrinking, membrane blebbing) [68]. However, such evidence is minimal for coffee extracts. One study reported co-administering coffee with anticancer agents but not coffee extract alone to distort MCF-7 cell morphology [79].
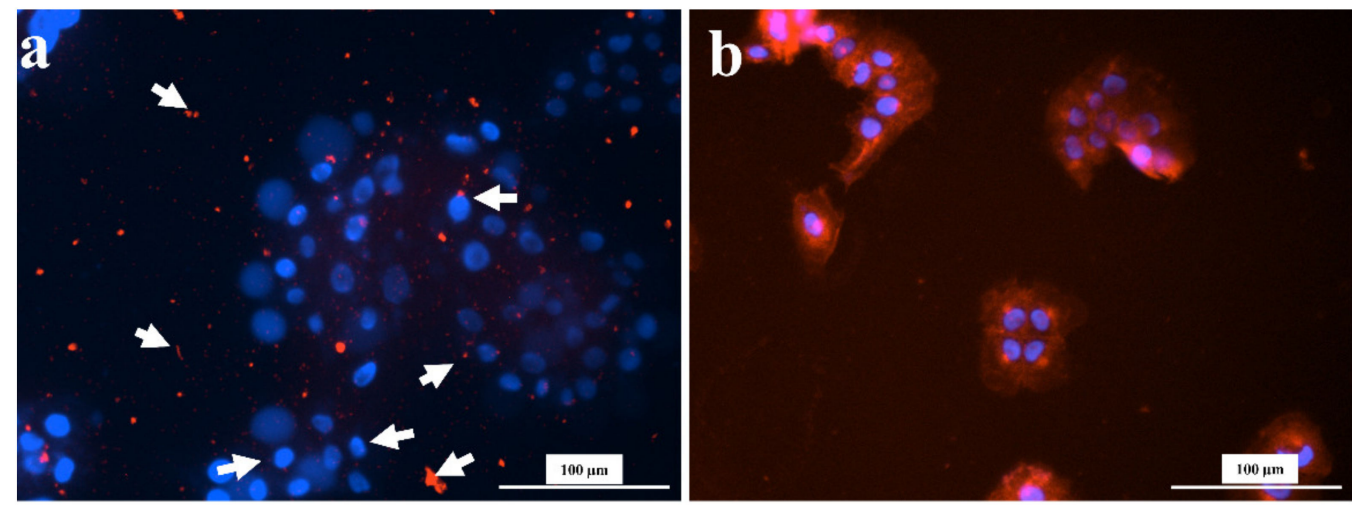

Figure 6. Morphological images (Cytation 3, 20×) of HaCaT cells after $12 \mathrm{~h}$ of treatment with $1.5 \mathrm{mg} / \mathrm{mL}$ of (a) tea and (b) coffee extracts. All images were recorded under the same conditions and presented with the same magnification for comparison.

\subsection{Morphological Analysis of Cells in the Presence of Hydrogels}

In this experiment, the impact of hydrogels on cell morphology was explored. Comparing control cells with cells in the vicinity of mini-gels (prepared from $100 \mu \mathrm{L}$ of 30B, $30 \mathrm{C}$, and 30T) shows that morphologically, there is not much difference across different treatments at both time points, $24 \mathrm{~h}$ and $48 \mathrm{~h}$ (Figure 7). The appearance of HaCaT cells in control, 30B, 30C, and 30T in the current study looks similar to that of the morphology reported previously $[78,80,81]$.

\subsection{Cell Viability Assessment of Media Incubated with Different Sizes of Hydrogel}

In this study, media treated with different sizes of hydrogel (50-500 $\mu \mathrm{L}$ of 30T, 30C, and 30B) was used for cell viability testing. Figure 8 shows that the cell viability values were $79.6 \pm 4.5 \%-6.6 \pm 0.5 \%$ for $50-500 \mu \mathrm{L}$ of blank hydrogel, $71.9 \pm 2.8 \%-6.9 \pm 1.5 \%$ for tea loaded hydrogel, and $86.7 \pm 7.5 \%-6.6 \pm 0.1 \%$ for coffee loaded hydrogel. The cell viability profile looks similar to all three formulations irrespective of the presence or absence of extracts. The cell viability values of mini-gels formed across different volumes of the three formulations (30T, 30C, 30B) were similar. These results indicate that the cell viability was not impacted by the presence of extracts in the formulation. However, this has also been evident from the data that blank gel shows the cell viability inhibition effects, which is evident from $79.6 \pm 4.5 \%$ cell viability from a small volume of $50 \mu \mathrm{L}$ of the blank hydrogel. 

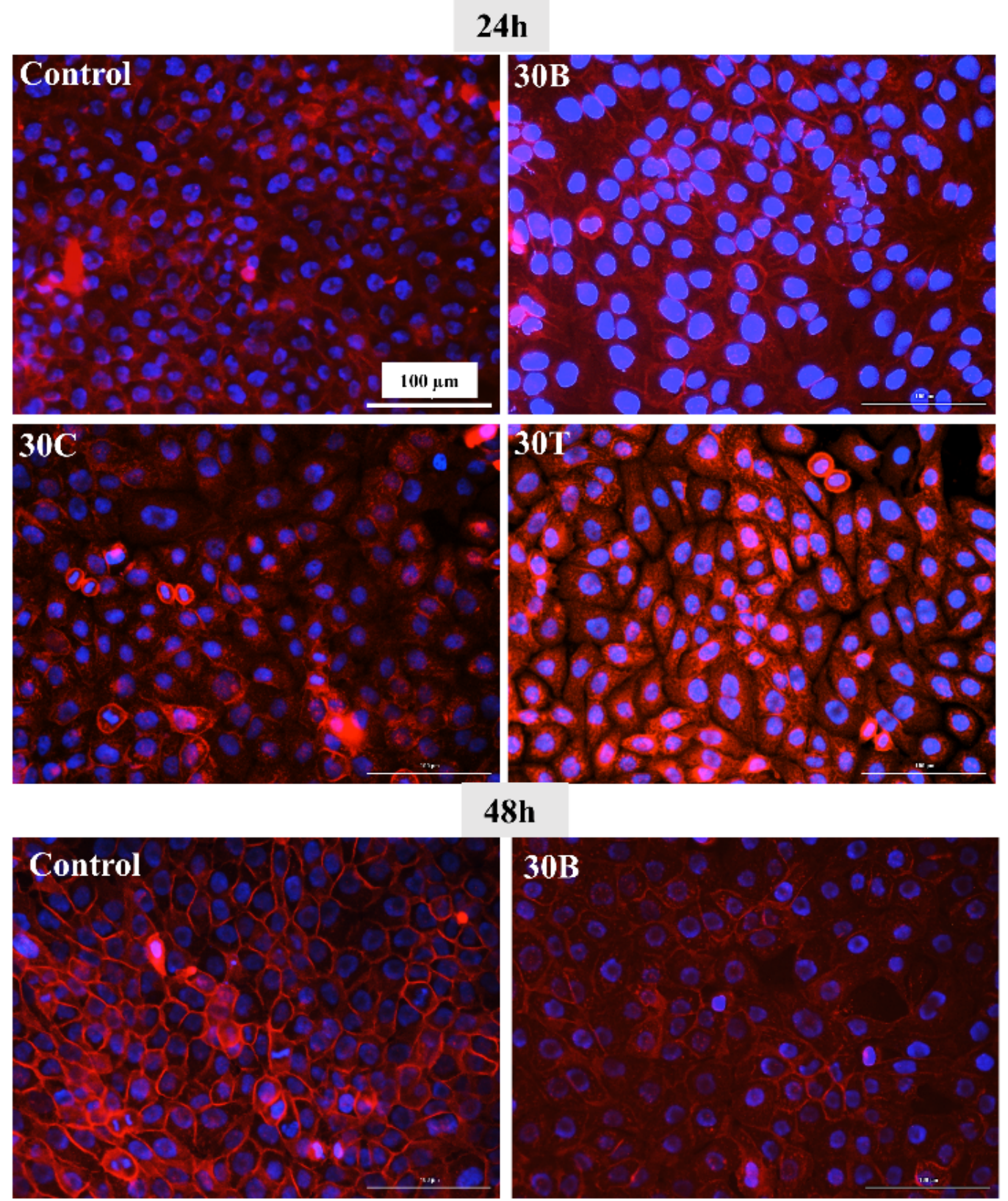

$30 \mathrm{~B}$
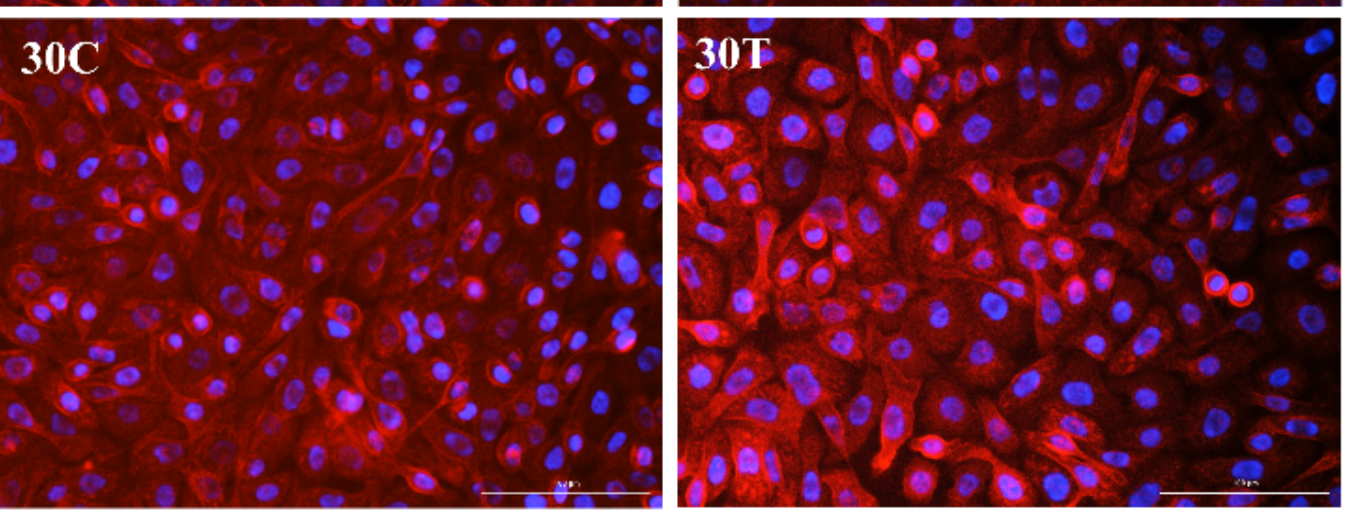

Figure 7. Morphological images (Cytation 3, 20X) of HaCaT cells after $24 \mathrm{~h}$ and $48 \mathrm{~h}$ of treatment with mini gel prepared from $100 \mu \mathrm{L}$ of 30B, 30C, 30T, and control. All images were recorded under the same conditions and presented with the same magnification for comparison. 


\section{$500 \square 200 \square 100 \square 50$}

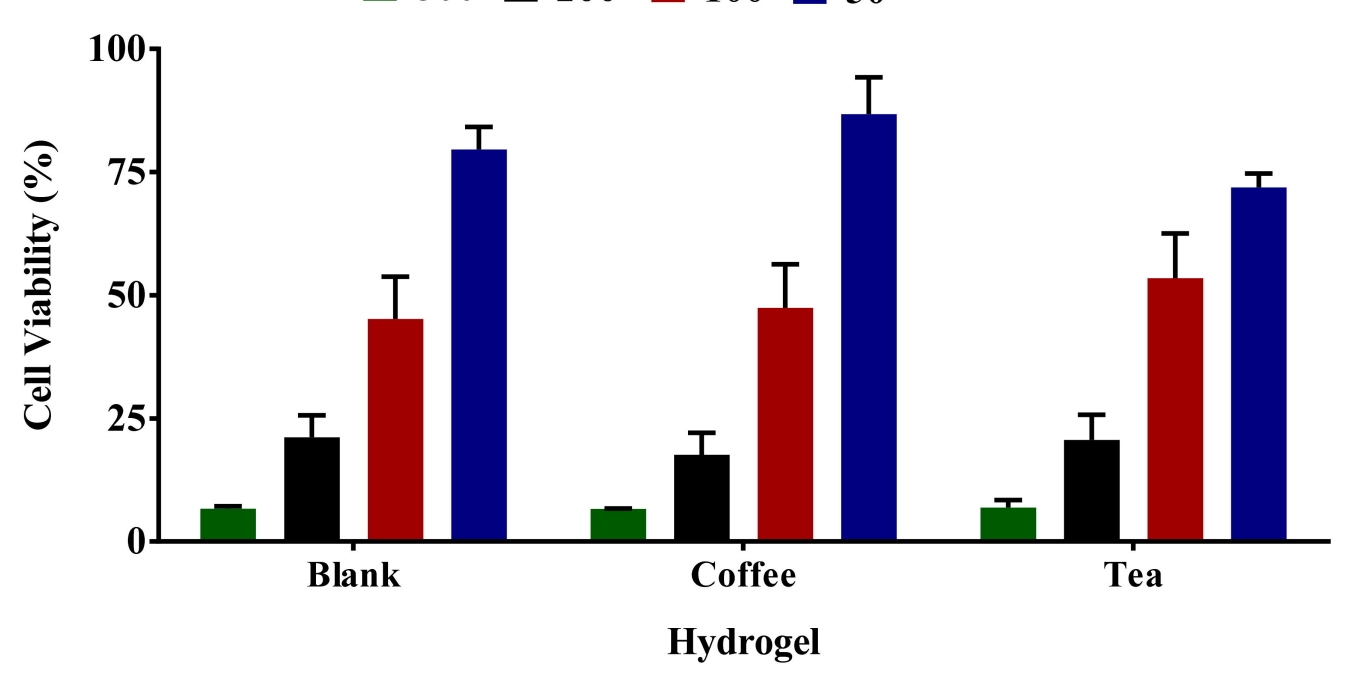

Figure 8. Different mini-gels of formulations were prepared for $24 \mathrm{~h}$ using different volumes $(50-500 \mu \mathrm{L})$ of gelling solution. DMEM media was used to soak gels. HaCaT cells were treated for $24 \mathrm{~h}$ with DMEM media used for gel soaking. Impact of media leachate obtained after $48 \mathrm{~h}$ soaking of mini gels 30B, 30C, and 30T was evaluated by MTT assay. The results from three independent experiments ( 3 replicates in each experiment) are presented as mean \pm standard deviation (SD).

Our study did not determine the amount of unreacted APS in gel potentially leaching into the cellular system, given that the gels were washed with phosphate-buffered saline (PBS) and Dulbecco's Modified Eagle Medium (DMEM) before setting up for leaching. It has been reported in the literature that exposing cells to APS concentrations of $100 \mathrm{mM}$ or $500 \mathrm{mM}$ lead for $2 \mathrm{~h}$ leads to a reduction in the fraction of live cells [82]. These findings have been confirmed in a different study [83]. One different aspect of MBA addition was highlighted in a study, where the time of complete utilization of MBA (in equivalent amount to the polymer) took three days [84] while the current study used only $24 \mathrm{~h}$ time. One study reported that MBA could cause toxicity with concentrations as low as $92 \pm 31 \mu \mathrm{M}$ in N1E-115 neuroblastoma [85]. In our study, $80.4 \mathrm{mM}$ MBA was used in $2 \mathrm{~mL}$ gel preparation; however, the unreacted MBA was not qualified.

This study also observed the impact of media incubation on gel (Supplementary Materials, Figure S4). The hydrogel's physical structure was distorted after incubation with media (Figure S4). The distorted structure shows the degradation of hydrogel in media. The color change to yellow (Figure S4b) indicates a decrease in $\mathrm{pH}$, a standard media indicator of $\mathrm{pH}$ change. This physical change can be attributed to enzymatic degradation in media. Moreover, the color changes reveal the availability of more acidic groups upon enzymatic degradation. These suggest that PAA hydrogels are sensitive to biological media or enzymes, which can be studied further to prepare and optimize enzyme-sensitive hydrogels for biomedical applications. It also reveals that the reduced cell viability of $\mathrm{HaCaT}$ cells might be due to degradation products. However, the reduced cell viability is not a concern for topical application on intact skin as the hydrogels will not contact biological fluids, which can avoid degradation.

\section{Conclusions}

This study explored the direct exposure aqueous extract of commercially available tea and coffee in skin cells. The tea and coffee extracts were toxic on direct and prolonged exposure at high doses on skin cells. Polymeric hydrogel retarded the tea and coffee release. Adding milk into tea hydrogels further controlled the tea release. The gels were rigid, with adhesive properties and high loading efficiency of $>70 \%$ of tea or coffee extract. The tea and coffee hydrogels were biocompatible with skin cells without any morphological changes. Overall, the tea and coffee-loaded hydrogel showed potential in the controlled 
delivery of tea and coffee extracts for skin application. The hydrogel properties were suitable to make bioadhesive mask for skin applications.

\section{Materials and Methods}

\subsection{Materials}

Black tea leaves were purchased from the Red label brand. Coffee was obtained as commercial use granulated lyophilized powder was obtained from Boncafe brand. UHT milk was obtained from the NTUC FairPrice brand. PAA $450 \mathrm{kDa}$, MBA, APS, and MTT were purchased from Sigma Aldrich, St. Louis, MO, USA. HaCaT cells were bought from the American Type Culture Collection (ATCC), Manassas, VA, USA. DMEM and fetal bovine serum were bought from Biowest, France. Penicillin-Streptomycin $(100 \times)$ was purchased from Thermo Fisher Scientific, Waltham, MA, USA.

\subsection{Black Tea Dry Extract Preparation}

Black tea extract preparation was done using a slight modification of the previously described method [86]. First, $8 \mathrm{~g}$ of black tea leaves were soaked in $400 \mathrm{~mL}$ deionized (DI) water maintained at a temperature of $28-30^{\circ} \mathrm{C}$ for $30 \mathrm{~min}$. Then, the extract obtained was filtered, frozen at $-80^{\circ} \mathrm{C}$, and freeze-dried to get a dry extract. Finally, the dried black tea extract was weighed and stored at $-20^{\circ} \mathrm{C}$ for further use.

\subsection{Cell Viability Assessment of Tea and Coffee Extracts}

The HaCaT cell line was subcultured in DMEM medium supplemented with $20 \%$ fetal bovine serum, $1 \%$ penicillin-streptomycin, and incubated in the presence of $5 \% \mathrm{CO}_{2}$ and $95 \%$ humidity at $37^{\circ} \mathrm{C}$ temperature. A cell suspension of $5 \times 10^{3}$ cells in $100 \mu \mathrm{L}$ of DMEM medium was seeded into each well of the 96-well plate and incubated overnight inside an incubator. These wells were treated with $100 \mu \mathrm{L}$ of DMEM medium containing tea and coffee extracts in such a way that the concentration of tea or coffee extracts was $0.025 \mathrm{mg} / \mathrm{mL}$, $0.05 \mathrm{mg} / \mathrm{mL}, 0.075 \mathrm{mg} / \mathrm{mL}, 0.1 \mathrm{mg} / \mathrm{mL}, 0.5 \mathrm{mg} / \mathrm{mL}, 1 \mathrm{mg} / \mathrm{mL}$, and $2 \mathrm{mg} / \mathrm{mL}$ inside different wells. The cells inside the control well were not exposed to any extract but only had the DMEM medium. After adding extracts, plates were incubated for $72 \mathrm{~h}$, followed by the addition of MTT reagent solution ( $20 \mu \mathrm{L}, 5 \mathrm{mg} / \mathrm{mL}$, Sigma Aldrich, USA) to each well and incubated again for $3 \mathrm{~h}$. The excess medium was aspirated, and $100 \mu \mathrm{L}$ dimethyl sulfoxide (DMSO) was added to each well. The optical density measurements (OD) were performed using a microplate reader (SPARK ${ }^{\mathrm{TM}} 10 \mathrm{M}$, Tecan, Männedorf, Switzerland) at $570 \mathrm{~nm}$. Relative cell viability was derived from the following Equation (1).

$$
\text { Cell viability }(\%)=\left(\frac{\text { OD of treated cells }}{\text { OD of media only controls }}\right) \times 100
$$

\subsection{Preparation of Hydrogels}

The PAA hydrogel formulation was adapted from Joshi et al. [74]. For the preparation of hydrogels without milk, $150 \mathrm{mg}$ of PAA was first dissolved in $2 \mathrm{~mL}$ of DI water or extract solution in DI water for 3-4 h. After the complete dissolution of PAA, $24.8 \mathrm{mg}$ of MBA and $50 \mathrm{mg}$ of APS were added. The mixture was stirred until dissolved. Next, the mixture was transferred to a $20 \mathrm{~mL}$ glass vial, capped, and kept at $70{ }^{\circ} \mathrm{C}$ for $24 \mathrm{~h}$ for gelation (Table 3). For preparing tea or coffee, hydrogels with milk, the volumes of water, and milk were taken, as per Table 3. Black tea dry extract or coffee extract (Table 3) was added to the water-milk solution. This mixture was slowly pipetted to ensure uniform mixing of tea or coffee components with the water-milk solution while avoiding bubble formation. Then, $150 \mathrm{mg}$ of PAA was dissolved in $2 \mathrm{~mL}$ of water-milk-tea or water-milk-coffee solution. As described above, MBA and APS addition were followed by gelation similar to the steps for preparing hydrogels without milk. 
Table 3. Formulation of PAA hydrogels loaded with black tea dry extract and coffee extract.

\begin{tabular}{ccccc}
\hline Formulation Code & Tea & Coffee & Water & Milk \\
\hline B & - & - & $2 \mathrm{~mL}$ & - \\
$30 \mathrm{~T}$ & $30 \mathrm{mg}$ & - & $2 \mathrm{~mL}$ & - \\
$40 \mathrm{~T}$ & $40 \mathrm{mg}$ & - & $2 \mathrm{~mL}$ & - \\
$50 \mathrm{~T}$ & $50 \mathrm{mg}$ & - & $2 \mathrm{~mL}$ & - \\
$30 \mathrm{~T}$ & $60 \mathrm{mg}$ & - & $2 \mathrm{~mL}$ & - \\
$30 \mathrm{C}$ & - & $30 \mathrm{mg}$ & $2 \mathrm{~mL}$ & - \\
$40 \mathrm{C}$ & - & $40 \mathrm{mg}$ & $2 \mathrm{~mL}$ & - \\
$50 \mathrm{C}$ & - & $50 \mathrm{mg}$ & $2 \mathrm{~mL}$ & - \\
$60 \mathrm{C}$ & - & $60 \mathrm{mg}$ & $2 \mathrm{~mL}$ & - \\
BM & - & - & $1.75 \mathrm{~mL}$ & $0.25 \mathrm{~mL}$ \\
$30 \mathrm{TM}$ & $30 \mathrm{mg}$ & - & $1.875 \mathrm{~mL}$ & $0.125 \mathrm{~mL}$ \\
$40 \mathrm{TM}$ & $40 \mathrm{mg}$ & - & $1.833 \mathrm{~mL}$ & $0.167 \mathrm{~mL}$ \\
$50 \mathrm{TM}$ & $50 \mathrm{mg}$ & - & $1.792 \mathrm{~mL}$ & $0.208 \mathrm{~mL}$ \\
$60 \mathrm{TM}$ & $60 \mathrm{mg}$ & - & $1.75 \mathrm{~mL}$ & $0.25 \mathrm{~mL}$ \\
$30 \mathrm{CM}$ & - & $30 \mathrm{mg}$ & $1.875 \mathrm{~mL}$ & $0.125 \mathrm{~mL}$ \\
$40 \mathrm{CM}$ & - & $40 \mathrm{mg}$ & $1.833 \mathrm{~mL}$ & $0.167 \mathrm{~mL}$ \\
$50 \mathrm{CM}$ & - & $50 \mathrm{mg}$ & $1.792 \mathrm{~mL}$ & $0.208 \mathrm{~mL}$ \\
$60 \mathrm{CM}$ & - & $60 \mathrm{mg}$ & $1.75 \mathrm{~mL}$ & $0.25 \mathrm{~mL}$ \\
\hline
\end{tabular}

$\mathrm{T}=$ Black tea extract; $\mathrm{TM}=$ Black tea extract and milk, $\mathrm{C}=$ coffee extract, $\mathrm{CM}=$ coffee extract and milk, $\mathrm{B}=$ blank formulation without milk, $\mathrm{BM}=$ blank formulation with milk; $30=30 \mathrm{mg}$ of extract; $40=40 \mathrm{mg}$ of extract; $50=50 \mathrm{mg}$ of extract; $60=60 \mathrm{mg}$ of extract.

\subsection{Loading Efficiency of Tea and Coffee in Hydrogels}

After $24 \mathrm{~h}$ of gelation, the supernatant liquid from individual gels prepared (using formulation from Table 3) was collected in separate vials. Each sample was suitably diluted and analyzed using a Shimadzu UV-Vis spectrophotometer (UV-3600) in a 200-800 nm wavelength range. The concentrations of the samples were determined using the calibration curve prepared using known quantities of the black tea and coffee extract (Figure S2). The calculated loading of tea or coffee extract in the hydrogel was calculated by subtracting the amount of tea or coffee left in the supernatant on the top of the hydrogel from the total amount of tea or coffee extract loaded hydrogel solution before keeping for gelation. Loading efficiency (\%) is calculated by Equation (2) below.

$$
\text { Loading efficiency }(\%)=\frac{(\text { Original amount added }- \text { Amount in supernatant })}{(\text { Original amount added })} \times 100
$$

\subsection{Release Study of the Hydrogels}

After collecting the supernatant, the surface of the gel was washed three times with DI water and kept upside down overnight to drain any traces of left-over water. For the release study, $10 \mathrm{~mL}$ of water was added to the gel's top while still attached to the $20 \mathrm{~mL}$ glass vial bottom. At different time points ( 4 h, 8 h, 12 h, 24 h, 48 h, 72 h, 96 h, 120 h), 1-2 mL of sample was withdrawn and replaced with an equal volume of fresh DI water. Each sample was suitably diluted and analyzed using a Shimadzu UV/Vis spectrophotometer (UV-3600) in a 200-800 $\mathrm{nm}$ wavelength range. The concentrations of the samples were determined using the calibration curve prepared using known quantities of the tea and coffee extract powder.

\subsection{Interaction of Tea or Coffee with Milk}

The size and zeta potential ( $\zeta$-potential) for tea extract or coffee extract with or without milk were obtained to understand interactions. Hence, $30 \mathrm{mg}$ of tea or coffee powder was dissolved in $2 \mathrm{~mL}$ of water or $2 \mathrm{~mL}$ of milk-water (1:15) mixture as prepared for 30TM/30T or $30 \mathrm{CM} / 30 \mathrm{C}$ (Table 3 ). The solutions were diluted as required to carry out particle size and $\zeta$-potentials measurements using Malvern Zetasizer Nano-ZS90. 


\subsection{Morphological Analysis of Cells}

Briefly, $100 \mu \mathrm{L}$ of 30T, 30C, and 30B hydrogel solution before gelling were poured in the corner of the 6-well plate and allowed to gel for $24 \mathrm{~h}$. After $24 \mathrm{~h}$, the gel surface was sterilized under UV for $15 \mathrm{~min}$, washed with $1 \mathrm{~mL}$ PBS, quickly followed by $1 \mathrm{~mL}$ of DMEM. Then, $5 \times 10^{5} \mathrm{HaCaT}$ cells were seeded in the individual wells (sparing the part containing the gel). Later, $3 \mathrm{~mL}$ of media was added to each well. The plate was incubated for $24 \mathrm{~h}$ and $48 \mathrm{~h}$ in an incubator. After $24 \mathrm{~h}$ and $48 \mathrm{~h}$, the media was removed from each well. Then, $1 \mathrm{~mL}$ of media containing CellMask ${ }^{\mathrm{TM}}$, orange plasma membrane stain (Thermofisher Scientific), and NucBlue ${ }^{\mathrm{TM}}$ live readyprobes ${ }^{\mathrm{TM}}$ reagent (Thermofisher Scientific) was added to the cells and kept under dark for 25-30 min. After incubation, the media with stains was removed, and the stained cells were washed gently with PBS 3 times. Later, $2 \mathrm{~mL}$ of PBS was added to cover the cells and prevent drying until imaged. Cells were photographed with a $20 \times$ objective lens on a Cytation 3 Cell Imaging Multi-Mode Reader (BioTek Instruments, Inc., Winooski, VT, USA) using a blue filter $(377,447)$ and a red filter $(586,647)$.

For the morphological analysis of cells with tea and coffee extracts, the cells were treated with $1.5 \mathrm{mg} / \mathrm{mL}$ of tea or coffee extract prepared in DMEM for $12 \mathrm{~h}$. After completion of treatment time, staining and imaging steps were the same as above.

\subsection{Cell Viability Assessment of Media Incubated with Different Sizes of Hydrogel}

The media treated with different sizes of hydrogel (after $48 \mathrm{~h}$ incubation in media) was used for cell viability testing. The hydrogels were prepared using gelling solutions of 30T, $30 \mathrm{C}$, and 30B (Table 3). Then, varying sizes of hydrogel were prepared by different volumes $(50 \mu \mathrm{L}, 100 \mu \mathrm{L}, 200 \mu \mathrm{L}, 500 \mu \mathrm{L}$ ) of 30T, 30C, and 30B (Table 3). The gelling solutions were poured into a 24 -well plate and allowed to gel at $70{ }^{\circ} \mathrm{C}$ for $24 \mathrm{~h}$. After $24 \mathrm{~h}$, mini-gels $(50 \mu \mathrm{L}$, $100 \mu \mathrm{L}, 200 \mu \mathrm{L}, 500 \mu \mathrm{L}$ volume) were formed, and the gel surface was sterilized under UV light for $15 \mathrm{~min}$. Then the surface was quickly washed with $1 \mathrm{~mL}$ PBS, followed by $1 \mathrm{~mL}$ of DMEM. This procedure was repeated three times to ensure no unreacted components from the surface leach out in the medium during the incubation process. After this, the gels were kept in contact with $2 \mathrm{~mL}$ of DMEM medium for $48 \mathrm{~h}$. After $48 \mathrm{~h}$, the medium was removed and stored at $-20^{\circ} \mathrm{C}$ until studied. The $\mathrm{HaCaT}$ cells were subcultured and seeded into each well of the 96-well plate as described in the previous section. After attachment, the cells were treated with leachate. The cells inside the control well were exposed to fresh media. After adding extracts, plates were incubated for $24 \mathrm{~h}$, followed by the addition of MTT reagent solution ( $20 \mu \mathrm{L}, 5 \mathrm{mg} / \mathrm{mL}$, Sigma Aldrich, USA) to each well and incubated again for $3 \mathrm{~h}$. Finally, the excess medium was aspirated, and DMSO $(100 \mu \mathrm{L})$ was added to each well. The optical density measurements (OD) were performed using a microplate reader (SPARK ${ }^{\mathrm{TM}} 10 \mathrm{M}$, Tecan, Switzerland) at $570 \mathrm{~nm}$. Relative cell viability was derived from Equation (1).

The cell viability assessment of hydrogel could not be performed using the general MTT assay protocol. The MTT assay is based on the optical density determination of formazan crystals. The reduction in cell viability is understood by the reduction in the optical density of formazan crystals. However, in the case of hydrogels, the hydrogel surface adsorbs formazan crystals during MTT incubation, which could not be dissolved even on the addition of DMSO, causing a false reduction in cell viability. Therefore, considering the limitation of the assay, an MTT assay was performed using media incubated with hydrogels.

\subsection{Statistical Analysis}

An unpaired t-test with Welch's correction was used for analyzing the data. All data are presented as a mean of 1-3 determinations \pm standard deviation of the mean. ${ }^{*}(p<0.05),{ }^{* *}(p<0.01),{ }^{* * *}(p<0.001)$ or ${ }^{* * *}(p<0.0001)$ show statistically significant differences compared to control unless otherwise stated. 
Supplementary Materials: The following are available online at https:/ /www.mdpi.com/article/ 10.3390/gels7040174/s1, Figure S1: Calibration curve of black tea and coffee extract, Figure S2: Physical appearances of blank hydrogels, Figure S3: Physical observation of gelling during optimization Figure S4: Effect of media on hydrogel integrity, Table S1: Optimization of PAA amount based on physical properties, Table S2: Optimization of Black tea extract loading with APS and MBA amounts, Table S3: Model-fitting of the release of tea and tea-milk hydrogels, Table S4: Model-fitting of the release of coffee and coffee-milk hydrogels, Video S1: Incomplete Hydrogel due to black tea addition.

Author Contributions: Conceptualization, P.M.; data curation, P.M.; formal analysis. P.M. and H.K.; funding acquisition, G.S. and B.G.; investigation, P.M.; methodology, P.M.; resources, G.S.; software, P.M. and H.K.; supervision, B.G.; visualization, P.M. and H.K.; writing-original draft, P.M., H.K., G.S. and B.G.; writing-review \& editing, P.M., H.K., G.S. and B.G. All authors have read and agreed to the published version of the manuscript.

Funding: NUS-IPP: Grant number: R-143-000-A02-592. This work was also supported by Ministry of Education Tier 1 Grant [R-184-000-301-114] to GS.

Data Availability Statement: The data presented in this study are available on request from the corresponding author.

Acknowledgments: Pooja Makhija thanks the National University of Singapore for support and research scholarship through the IRP program.

Conflicts of Interest: The authors declare no conflict of interest.

\section{References}

1. Li, S.; Lo, C.-Y.; Pan, M.-H.; Lai, C.-S.; Ho, C.-T. Black tea: Chemical analysis and stability. Food Funct. 2013, 4, 10-18. [CrossRef]

2. Tanaka, T.; Mine, C.; Inoue, K.; Matsuda, M.; Kouno, I. Synthesis of theaflavin from epicatechin and epigallocatechin by plant homogenates and role of epicatechin quinone in the synthesis and degradation of theaflavin. J. Agric. Food Chem. 2002, 50, 2142-2148. [CrossRef]

3. Koch, W.; Zagorska, J.; Marzec, Z.; Kukula-Koch, W. Applications of Tea (Camellia sinensis) and Its Active Constituents in Cosmetics. Molecules 2019, 24, 4277. [CrossRef]

4. Drynan, J.W.; Clifford, M.N.; Obuchowicz, J.; Kuhnert, N. The chemistry of low molecular weight black tea polyphenols. Nat. Prod. Rep. 2010, 27, 417-462. [CrossRef]

5. Lewis, J.R.; Davis, A.L.; Cai, Y.; Davies, A.P.; Wilkins, J.P.G.; Pennington, M. Theaflavate B, ISOTHEAFLAVIN-3'-O-GALLATE and NEOTHEAFLAVIN-3-O-GALLATE: Three polyphenolic pigments from black tea. Phytochemistry 1998, 49, 2511-2519. [CrossRef]

6. Nonaka, G.-I.; Hashimoto, F.; Nishioka, I. Tannins and related compounds. XXXVI. Isolation and structures of theaflagallins, new red pigments from black tea. Chem. Pharm. Bull. 1986, 34, 61-65. [CrossRef]

7. Berkowitz, J.E.; Coggon, P.; Sanderson, G.W. Formation of epitheaflavic acid and its transformation to thearubigins during tea fermentation. Phytochemistry 1971, 10, 2271-2278. [CrossRef]

8. Jabir, N.R.; Islam, M.T.; Tabrez, S.; Shakil, S.; Zaidi, S.K.; Khan, F.R.; Araújo, L.d.S.; de Meneses, A.-A.P.M.; Santos, J.V.d.O.; Melo-Cavalcante, A.A.d.C. An insight towards anticancer potential of major coffee constituents. BioFactors 2018, 44, 315-326. [CrossRef]

9. Hall, S.; Yuen, J.; Grant, G. Bioactive constituents in caffeinated and decaffeinated coffee and their effect on the risk of depressionA comparative constituent analysis study. Beverages 2018, 4, 79. [CrossRef]

10. Islam, M.T.; Tabrez, S.; Jabir, N.R.; Ali, M.; Kamal, M.A.; da Silva Araujo, L.; De Oliveira Santos, J.V.; da Mata, A.M.O.F.; de Aguiar, R.P.S.; de Carvalho, A.A.M.C. An insight into the therapeutic potential of major coffee components. Curr. Drug Metab. 2018, 19, 544-556. [CrossRef] [PubMed]

11. Segheto, L.; Santos, B.C.S.; Werneck, A.F.L.; Vilela, F.M.P.; de Sousa, O.V.; Rodarte, M.P. Antioxidant extracts of coffee leaves and its active ingredient 5-caffeoylquinic acid reduce chemically-induced inflammation in mice. Ind. Crop. Prod. 2018, 126, 48-57. [CrossRef]

12. Perrone, D.; Donangelo, C.M.; Farah, A. Fast simultaneous analysis of caffeine, trigonelline, nicotinic acid and sucrose in coffee by liquid chromatography-mass spectrometry. Food Chem. 2008, 110, 1030-1035. [CrossRef] [PubMed]

13. Funakoshi-Tago, M.; Nonaka, Y.; Tago, K.; Takeda, M.; Ishihara, Y.; Sakai, A.; Matsutaka, M.; Kobata, K.; Tamura, H. Pyrocatechol, a component of coffee, suppresses LPS-induced inflammatory responses by inhibiting NF- $\mathrm{KB}$ and activating Nrf2. Sci. Rep. 2020, 10, 2584. [CrossRef]

14. Allred, K.F.; Yackley, K.M.; Vanamala, J.; Allred, C.D. Trigonelline is a novel phytoestrogen in coffee beans. J. Nutr. 2009, 139, 1833-1838. [CrossRef]

15. Ngamdokmai, N.; Ingkaninan, K.; Chaichamnong, N.; Chootip, K.; Neungchamnong, N.; Waranuch, N. Development, characterization, and stability evaluation of the anti-cellulite emgel containing herbal extracts and essential oils. Pharmaceuticals 2021, 14, 842. [CrossRef] 
16. Zheng, X.; Feng, M.; Wan, J.; Shi, Y.; Xie, X.; Pan, W.; Hu, B.; Wang, Y.; Wen, H.; Wang, K.; et al. Anti-damage effect of theaflavin-3'-gallate from black tea on UVB-irradiated HaCaT cells by photoprotection and maintaining cell homeostasis. J. Photochem. Photobiol. B Biol. 2021, 224, 112304. [CrossRef]

17. Lee, S.F.; Liang, Y.C.; Lin, J.K. Inhibition of 1,2,4-benzenetriol-generated active oxygen species and induction of phase II enzymes by green tea polyphenols. Chem. Biol. Interact. 1995, 98, 283-301. [CrossRef]

18. Hakim, I.A.; Harris, R.B.; Brown, S.; Chow, H.-H.; Wiseman, S.; Agarwal, S.; Talbot, W. Effect of increased tea consumption on oxidative DNA damage among smokers: A randomized controlled study. J. Nutr. 2003, 133, 3303S-3309S. [CrossRef]

19. O'Sullivan, J.; Sheridan, J.; Mulcahy, H.; Tenniswood, M.; Morrissey, C. The effect of green tea on oxidative damage and tumour formation in Lobund-Wistar rats. Eur. J. Cancer Prev. 2008, 17, 489-501. [CrossRef]

20. Imran, A.; Butt, M.S.; Xiao, H.; Imran, M.; Rauf, A.; Mubarak, M.S.; Ramadan, M.F. Inhibitory effect of black tea (Camellia sinensis) theaflavins and thearubigins against HCT 116 colon cancer cells and HT 460 lung cancer cells. J. Food Biochem. 2019, 43, e12822. [CrossRef] [PubMed]

21. Wang, Y.; Ren, N.; Rankin, G.O.; Li, B.; Rojanasakul, Y.; Tu, Y.; Chen, Y.C. Anti-proliferative effect and cell cycle arrest induced by saponins extracted from tea (Camellia sinensis) flower in human ovarian cancer cells. J. Funct. Foods 2017, 37, 310-321. [CrossRef]

22. Ramlagan, P.; Rondeau, P.; Planesse, C.; Neergheen-Bhujun, V.S.; Bourdon, E.; Bahorun, T. Comparative suppressing effects of black and green teas on the formation of advanced glycation end products (AGEs) and AGE-induced oxidative stress. Food Funct. 2017, 8, 4194-4209. [CrossRef]

23. Abubakr, M.; Hassan, Z.; Imdakim, M.; Sharifah, N.R. Antioxidant activity of lactic acid bacteria (LAB) fermented skim milk as determined by 1,1-diphenyl-2-picrylhydrazyl (DPPH) and ferrous chelating activity (FCA). Afr. J. Microbiol. Res. 2012, 6, 6358-6364. [CrossRef]

24. Li, Y.; Shi, J.; Sun, X.; Li, Y.; Duan, Y.; Yao, H. Theaflavic acid from black tea protects PC12 cells against ROS-mediated mitochondrial apoptosis induced by OGD/R via activating Nrf2/ARE signaling pathway. J. Nat. Med. 2020, 74, 238-246. [CrossRef]

25. Lagha, A.B.; Grenier, D. Tea polyphenols protect gingival keratinocytes against TNF- $\alpha$-induced tight junction barrier dysfunction and attenuate the inflammatory response of monocytes/macrophages. Cytokine 2019, 115, 64-75. [CrossRef] [PubMed]

26. Peluso, I.; Serafini, M. Antioxidants from black and green tea: From dietary modulation of oxidative stress to pharmacological mechanisms. Br. J. Pharmacol. 2017, 174, 1195-1208. [CrossRef] [PubMed]

27. Martini, D.; Del Bo, C.; Tassotti, M.; Riso, P.; del Rio, D.; Brighenti, F.; Porrini, M. Coffee consumption and oxidative stress: A review of human intervention studies. Molecules 2016, 21, 979. [CrossRef]

28. León, D.; Medina, S.; Londoño-Londoño, J.; Jiménez-Cartagena, C.; Ferreres, F.; Gil-Izquierdo, A. Chapter 3. Anti-inflammatory activity of Coffee. In Coffee; The Royal Society of Chemistry: London, UK, 2019; pp. 57-74.

29. Chatterjee, P.; Chandra, S.; Dey, P.; Bhattacharya, S. Evaluation of anti-inflammatory effects of green tea and black tea: A comparative in vitro study. J. Adv. Pharm. Technol. Res. 2012, 3, 136-138. [CrossRef] [PubMed]

30. Lania, B.G.; Morari, J.; Souza, A.L.; Silva, M.N.D.; de Almeida, A.R.; Veira-Damiani, G.; Alegre, S.M.; Cesar, C.L.; Velloso, L.A.; Cintra, M.L.; et al. Topical use and systemic action of green and roasted coffee oils and ground oils in a cutaneous incision model in rats (Rattus norvegicus albinus). PLoS ONE 2017, 12, e0188779. [CrossRef]

31. Hajiaghaalipour, F.; Kanthimathi, M.S.; Abdulla, M.A.; Sanusi, J. The effect of Camellia sinensis on wound healing potential in an animal model. Evid.-Based Complement. Alternat. Med. 2013, 2013, 386734. [CrossRef] [PubMed]

32. Hailemeskel, B.; Fullas, F. The use of freshly roasted coffee bean powder in the treatment of burn wound: A case report. Dermatol. Open J. 2016, 1, 42-46. [CrossRef]

33. Humaryanto; Ave, O.R. Exploring the potential of green coffee extract for wound healing treatment. IOP Conf. Ser. Environ. Earth Sci. 2019, 391, 012057. [CrossRef]

34. Sopyan, I.; Permata, R.D.; Gozali, D.; Syah, I.S.K. Formulation of lotion from black tea extract (Camellia sinensis linnaeus) as sunscreen. Int. J. Appl. Pharm. 2019, 11, 205. [CrossRef]

35. Chen, Z.; Wang, C.; Chen, J.; Li, X. Biocompatible, functional spheres based on oxidative coupling assembly of green tea polyphenols. J. Am. Chem. Soc. 2013, 135, 4179-4182. [CrossRef] [PubMed]

36. Chen, G.; He, L.; Zhang, P.; Zhang, J.; Mei, X.; Wang, D.; Zhang, Y.; Ren, X.; Chen, Z. Encapsulation of green tea polyphenol nanospheres in PVA/alginate hydrogel for promoting wound healing of diabetic rats by regulating PI3K/AKT pathway. Mater. Sci. Eng. C 2020, 110, 110686. [CrossRef]

37. Leite, M.G.A.; Campos, P.M. Photoprotective effects of a multifunctional hair care formulation containing botanical extracts, vitamins, and UV filters. Photochem. Photobiol. 2018, 94, 1010-1016. [CrossRef]

38. Waranuch, N.; Phimnuan, P.; Yakaew, S.; Nakyai, W.; Grandmottet, F.; Onlom, C.; Srivilai, J.; Viyoch, J. Antiacne and antiblotch activities of a formulated combination of Aloe barbadensis leaf powder, Garcinia mangostana peel extract, and Camellia sinensis leaf extract. Clin. Cosmet. Investig. Dermatol. 2019, 12, 383-391. [CrossRef]

39. Er, S.; Dikmen, M. Camellia sinensis increased apoptosis on U2OS osteosarcoma cells and wound healing potential on NIH3T3 fibroblast cells. Cytotechnology 2017, 69, 901-914. [CrossRef]

40. TJORI. TJORI-Anti Aging Coffee Gel. Available online: https://www.tjori.com/p/anti-aging-coffee-gel/57310/ (accessed on 31 May 2021).

41. St.Botanica. St.Botanica Scientifically Natural. Available online: https:/ / stbotanica.com/shop/skin/ (accessed on 31 May 2021). 
42. Kenisa, Y.P.; Istiati, I.; Wisnu, S.J. Effect of Robusta coffee beans ointment on full thickness wound healing. Dent. J. Maj. Kedokt. Gigi 2012, 45, 6. [CrossRef]

43. Priya, S.L.; Jagannathan, R.; Balaji, T.M.; Varadarajan, S.; Venkatakrishnan, C.; Rajendran, S.; Prabhu, D.V.R.; Francis, C.; Devi, S. Resveratrol and green coffee extract gel as anticaries agent. Indian J. Res. Pharm. Biotechnol. 2020, 8, 15-21. [CrossRef]

44. El-Wakil, N.A.; Hassan, E.A.; Hassan, M.L.; El-Salam, S.S.A. Bacterial cellulose/phytochemical's extracts biocomposites for potential active wound dressings. Environ. Sci. Pollut. Res. Int. 2019, 26, 26529-26541. [CrossRef]

45. Rodrigues, F.; Alves, A.C.; Nunes, C.; Sarmento, B.; Amaral, M.H.; Reis, S.; Oliveira, M.B. Permeation of topically applied caffeine from a food by-product in cosmetic formulations: Is nanoscale in vitro approach an option? Int. J. Pharm. 2016, 513, 496-503. [CrossRef]

46. Rodrigues, F.; Gaspar, C.; Palmeira-de-Oliveira, A.; Sarmento, B.; Amaral, M.H.; Oliveira, M.B.P.P. Application of coffee Silverskin in cosmetic formulations: Physical/antioxidant stability studies and cytotoxicity effects. Drug Dev. Ind. Pharm. 2016, 42, 99-106. [CrossRef]

47. Ye, J.-H.; Fan, F.; Xu, X.; Liang, Y. Interactions of black and green tea polyphenols with whole milk. Food Res. Int. 2013, 53, 449-455. [CrossRef]

48. Haratifar, S.; Meckling, K.A.; Corredig, M. Bioefficacy of tea catechins encapsulated in casein micelles tested on a normal mouse cell line (4D/WT) and its cancerous counterpart (D/v-src) before and after in vitro digestion. Food Funct. 2014, 5, 1160-1166. [CrossRef]

49. Guri, A.; Haratifar, S.; Corredig, M. Bioefficacy of tea catechins associated with milk caseins tested using different in vitro digestion models. Food Dig. 2014, 5, 8-18. [CrossRef]

50. Malekhosseini, P.; Alami, M.; Khomeiri, M.; Esteghlal, S.; Nekoei, A.R.; Hosseini, S.M.H. Development of casein-based nanoencapsulation systems for delivery of epigallocatechin gallate and folic acid. Food Sci. Nutr. 2019, 7, 519-527. [CrossRef]

51. Gülseren, İ.; Guri, A.; Corredig, M. Encapsulation of tea polyphenols in nanoliposomes prepared with milk phospholipids and their effect on the viability of HT-29 human carcinoma cells. Food Dig. 2012, 3, 36-45. [CrossRef]

52. Hasni, I.; Bourassa, P.; Hamdani, S.; Samson, G.; Carpentier, R.; Tajmir-Riahi, H.-A. Interaction of milk $\alpha$ - and $\beta$-caseins with tea polyphenols. Food Chem. 2011, 126, 630-639. [CrossRef]

53. Liu, C.; He, W.; Chen, S.; Chen, J.; Zeng, M.; Qin, F.; He, Z. Interactions of digestive enzymes and milk proteins with tea catechins at gastric and intestinal pH. Int. J. Food Sci. Technol. 2017, 52, 247-257. [CrossRef]

54. Yildirim-Elikoglu, S.; Erdem, Y.K. Interactions between milk proteins and polyphenols: Binding mechanisms, related changes, and the future trends in the dairy industry. Food Rev. Int. 2018, 34, 665-697. [CrossRef]

55. Kimpel, F.; Schmitt, J.J. Review: Milk proteins as nanocarrier systems for hydrophobic nutraceuticals. J. Food Sci. 2015, 80, R2361-R2366. [CrossRef]

56. Thompson, A.K.; Couchoud, A.; Singh, H. Comparison of hydrophobic and hydrophilic encapsulation using liposomes prepared from milk fat globule-derived phospholipids and soya phospholipids. Dairy Sci. Technol. 2009, 89, 99-113. [CrossRef]

57. Farhang, B.; Kakuda, Y.; Corredig, M. Encapsulation of ascorbic acid in liposomes prepared with milk fat globule membranederived phospholipids. Dairy Sci. Technol. 2012, 92, 353-366. [CrossRef]

58. Rashidinejad, A.; Tarhan, O.; Rezaei, A.; Capanoglu, E.; Boostani, S.; Khoshnoudi-Nia, S.; Samborska, K.; Garavand, F.; Shaddel, R.; Akbari-Alavijeh, S.; et al. Addition of milk to coffee beverages; the effect on functional, nutritional, and sensorial properties. Crit. Rev. Food Sci. Nutr. 2021, 1-21, online ahead of print. [CrossRef]

59. Liu, J.; Wang, Q.; Zhang, H.; Yu, D.; Jin, S.; Ren, F. Interaction of chlorogenic acid with milk proteins analyzed by spectroscopic and modeling methods. Spectrosc. Lett. 2016, 49, 44-50. [CrossRef]

60. Budryn, G.; Palecz, B.; Rachwal-Rosiak, D.; Oracz, J.; Zaczynska, D.; Belica, S.; Navarro-Gonzalez, I.; Meseguer, J.M.; Perez-Sanchez, H. Effect of inclusion of hydroxycinnamic and chlorogenic acids from green coffee bean in $\beta$-cyclodextrin on their interactions with whey, egg white and soy protein isolates. Food Chem. 2015, 168, 276-287. [CrossRef] [PubMed]

61. Turkoglu, M.; Cigirgil, N. Evaluation of black tea gel and its protection potential against UV. Int. J. Cosmet. Sci. 2007, 29, 437-442. [CrossRef] [PubMed]

62. Turkoglu, M.; Ugurlu, T.; Gedik, G.; Yilmaz, A.M.; Yalcin, A.S. In vivo evaluation of black and green tea dermal products against UV radiation. Drug Discov. Ther. 2010, 4, 362-367.

63. Van Gheluwe, L.; Chourpa, I.; Gaigne, C.; Munnier, E. Polymer-based smart drug delivery systems for skin application and demonstration of stimuli-responsiveness. Polymers 2021, 13, 1285. [CrossRef]

64. Zhu, J.; Han, H.; Ye, T.T.; Li, F.X.; Wang, X.L.; Yu, J.Y.; Wu, D.Q. Biodegradable and pH sensitive peptide based hydrogel as controlled release system for antibacterial wound dressing application. Molecules 2018, 23, 3383. [CrossRef] [PubMed]

65. Li, F.; Shanmugam, M.K.; Chen, L.; Chatterjee, S.; Basha, J.; Kumar, A.P.; Kundu, T.K.; Sethi, G. Garcinol, a polyisoprenylated benzophenone modulates multiple proinflammatory signaling cascades leading to the suppression of growth and survival of head and neck carcinoma. Cancer Prev. Res. 2013, 6, 843-854. [CrossRef]

66. Esghaei, M.; Ghaffari, H.; Esboei, B.R.; Tapeh, Z.E.; Salim, F.B.; Motevalian, M. Evaluation of anticancer activity of Camellia sinensis in the Caco-2 colorectal cancer cell line. Asian Pac. J. Cancer Prev. 2018, 19, 1697-1701. [CrossRef] [PubMed]

67. Konarikova, K.; Jezovicova, M.; Kerestes, J.; Gbelcova, H.; Durackova, Z.; Zitnanova, I. Anticancer effect of black tea extract in human cancer cell lines. Springerplus 2015, 4, 127. [CrossRef] [PubMed]

68. Sun, L.; Zhang, Y.; Zhang, W.; Lai, X.; Li, Q.; Zhang, L.; Sun, S. Green tea and black tea inhibit proliferation and migration of HepG2 cells via the PI3K/Akt and MMPs signalling pathway. Biomed. Pharmacother. 2020, 125, 109893. [CrossRef] [PubMed] 
69. Bauer, D.; Abreu, J.; Jordao, N.; Rosa, J.S.D.; Freitas-Silva, O.; Teodoro, A. Effect of roasting levels and drying process of coffea canephora on the quality of bioactive compounds and cytotoxicity. Int. J. Mol. Sci. 2018, 19, 3407. [CrossRef]

70. Xuan, S.H.; Lee, K.S.; Jeong, H.J.; Park, Y.M.; Ha, J.H.; Park, S.N. Cosmeceutical activities of ethanol extract and its ethyl acetate fraction from coffee silverskin. Biomater. Res. 2019, 23, 2. [CrossRef]

71. Ramalakshmi, K.; Rao, L.J.M.; Takano-Ishikawa, Y.; Goto, M. Bioactivities of low-grade green coffee and spent coffee in different in vitro model systems. Food Chem. 2009, 115, 79-85. [CrossRef]

72. Affonso, R.C.; Voytena, A.P.; Fanan, S.; Pitz, H.; Coelho, D.S.; Horstmann, A.L.; Pereira, A.; Uarrota, V.G.; Hillmann, M.C.; Varela, L.A.; et al. Phytochemical composition, antioxidant activity, and the effect of the aqueous extract of coffee (Coffea arabica L.) Bean residual press cake on the skin wound healing. Oxid. Med. Cell. Longev. 2016, 2016, 1923754. [CrossRef]

73. Imran, A.; Sadiq Butt, M.; Saeed, F.; Sajid Arshad, M.; Sultan, T.; Sohaib, M. Effect of different time-solvent interactions on polyphenol content of milky tea. J. Food Process. Preserv. 2017, 41, e13039. [CrossRef]

74. Joshi, S.; Mahadevan, G.; Verma, S.; Valiyaveettil, S. Bioinspired adenine-dopamine immobilized polymer hydrogel adhesives for tissue engineering. Chem. Commun. 2020, 56, 11303-11306. [CrossRef]

75. Haratifar, S.; Corredig, M. Interactions between tea catechins and casein micelles and their impact on renneting functionality. Food Chem. 2014, 143, 27-32. [CrossRef]

76. Narita, Y.; Inouye, K. Chlorogenic acids from coffee. In Coffee in Health and Disease Prevention; Preedy, V.R., Ed.; Academic Press: San Diego, CA, USA, 2015; pp. 189-199.

77. Bruschi, M.L. (Ed.) Mathematical models of drug release. In Strategies to Modify the Drug Release from Pharmaceutical Systems; Woodhead Publishing: Sawston, UK, 2015; pp. 63-86.

78. Dutta, D.; Markhoff, J.; Suter, N.; Rezwan, K.; Brüggemann, D. Effect of collagen nanofibers and silanization on the interaction of HaCaT keratinocytes and 3T3 fibroblasts with alumina nanopores. ACS Appl. Bio Mater. 2021, 4, 1852-1862. [CrossRef]

79. Funakoshi-Tago, M.; Tago, K.; Li, C.; Hokimoto, S.; Tamura, H. Coffee decoction enhances tamoxifen proapoptotic activity on MCF-7 cells. Sci. Rep. 2020, 10, 19588. [CrossRef]

80. Colombo, I.; Sangiovanni, E.; Maggio, R.; Mattozzi, C.; Zava, S.; Corbett, Y.; Fumagalli, M.; Carlino, C.; Corsetto, P.A.; Scaccabarozzi, D.; et al. HaCaT cells as a reliable in vitro differentiation model to dissect the inflammatory/repair response of human keratinocytes. Mediat. Inflamm. 2017, 2017, 7435621. [CrossRef]

81. Alarifi, S.; Ali, D.; Verma, A.; Alakhtani, S.; Ali, B.A. Cytotoxicity and genotoxicity of copper oxide nanoparticles in human skin keratinocytes cells. Int. J. Toxicol. 2013, 32, 296-307. [CrossRef] [PubMed]

82. Temenoff, J.S.; Shin, H.; Conway, D.E.; Engel, P.S.; Mikos, A.G. In vitro cytotoxicity of redox radical initiators for cross-linking of oligo(poly(ethylene glycol) fumarate) macromers. Biomacromolecules 2003, 4, 1605-1613. [CrossRef] [PubMed]

83. Kasparkova, V.; Humpolicek, P.; Stejskal, J.; Capakova, Z.; Bober, P.; Skopalova, K.; Lehocky, M. Exploring the critical factors limiting polyaniline biocompatibility. Polymers 2019, 11,362. [CrossRef]

84. Hunt, J. Frontiers in biomedical polymer applications: Volume 1. Mater. Today 1999, 2, 22-23. [CrossRef]

85. Brat, D.J.; Brimijoin, S. Acrylamide and glycidamide impair neurite outgrowth in differentiating N1E.115 neuroblastoma without disturbing rapid bidirectional transport of organelles observed by video microscopy. J. Neurochem. 1993, 60, 2145-2152. [CrossRef] [PubMed]

86. Labbé, D.; Têtu, B.; Trudel, D.; Bazinet, L. Catechin stability of EGC- and EGCG-enriched tea drinks produced by a two-step extraction procedure. Food Chem. 2008, 111, 139-143. [CrossRef] 